\title{
Feronia elephantum Correa: A Potential Traditional Drug
}

\author{
Review Article
}

\section{Mrinal Sharma1, Sanjay Nagdev²*, Mayur Bhurat ${ }^{3}$, Amitkumar Dhankani4, Mayur Jain ${ }^{5}$, Gaurav Mude 6}

1. Assistant Professor, Department of Pharmacology, Sachdeva College of Pharmacy, Gharuan.

4. Assistant Professor, Department of Pharmaceutics, PSGVP Mandal's College of Pharmacy, Shahada,

2. Assistant Professor, Department of Pharmaceutical Analysis, 3. Head Department of Pharmacognosy, 5. Assistant Professor, Department of Pharmaceutical Chemistry, 6. Assistant Professor, Department of Pharmacology,

Shri Prakashchand Jain College of Pharmacy and Research, Palaskhede (Bk.), Jamner, Maharashtra.

\begin{abstract}
There are number of herbal plants used as medicines from the ancient time. Chemical constituents from those plants isolated for wide range of diseased condition utilizes in from the ancient times in Ayurveda, Unani, Siddha etc. systems. Feronia elephantum Correa from the family Rutaceae also known as Kaith, Wood apple is one of them which have many chemical constituents with important medicinal purposes and diseases like Diabetes mellitus, ulcer, as diuretic, liver tonic etc. Leaves of the plant are astringent, carminative and prescribed for vomiting, dysentery, hiccough, indigestion and slight bowel affections of children. The fruits are used as dessert, source of beverages and juices. The fruit pulp is used externally as a remedy for certain insect bite. The bark is aromatic and cooling, useful in vitiated conditions of pitta. It is indigenous in South India, Java, Myanmar, Malaysia and Ceylon and cultivated in many parts of India. This plant is already used traditionally in Sri Lanka for many purposes like vomiting, dysentery etc. Chemical constituents isolated from the plant different parts already investigated for many pharmacological and pharmaceutical activities like Anti-ulcer, Antidiabetic, Antimicrobial, Antibacterial, Antioxidant, cytotoxic, Antitumor, Antihistaminic, Hepatoprotective, Antifungal, Antifertility and Anti-inflammatory. This article is an attempt to compile all the details of plant Feronia elephantum Correa.
\end{abstract}

Key Words: Herbal, Feronia Elephantum, Pharmacological, Rutaceae, Medicinal.

\section{Introduction}

The nature gifted plants or herbs always considered in the medicinal uses from the ancient times in Ayurveda, Unani etc. systems. There are so many medicinal plants available already in market for different disease as well for immune system improvement they are considered more effective with no toxic effects (1). Feronia elephantum Correa from family Rutaceae is one of rare medicinal plants also known as Kaith, Wood apple to treat many diseases like Diabetes mellitus, ulcer, as diuretic, liver tonic etc. (2, 3). Leaves of the plant are astringent, carminative and prescribed for vomiting, dysentery, hiccough, indigestion and slight bowel affections of children (4). The fruits are used as dessert, source of beverages and juices. The fruit pulp is used externally as a remedy for certain insect bite (5). The bark is aromatic and cooling, useful in vitiated conditions of pitta (6). Various search

\section{* Corresponding Author:}

\section{Sanjay Nagdev}

Assistant Professor, Department of Pharmaceutical

Analysis, Shri Prakashchand Jain College of

Pharmacy and Research, Palaskhede (Bk.),

Jamner, Maharashtra. India.

Email Id: snsanjurocks@,gmail.com engines like pubmed, Google scholar etc. were used to collect the data and the main aim of this review is to compile all the details of plant Feronia elephantum Correa which will serve other researchers and scientists for further investigations of unexplored potentials of this plant and till date there is no review article is available on this plant, In this context, we have deliberated various aspects of plant Feronia elephantum Correa.

\section{Taxonomical classification}

- Kingdom: Plantae

- Phylum: Magnoliophta

- Class: Magnoliopsida

- Order: Sapindales

- Family: Rutaceae

- Genus: Feronia. (7)

\section{Vernacular names}

- Sanskrit: Kapittha

- Hindi: Kaith, Katbel

- Bengali: Kadbel

- Tamil: Vila, Vilankay maram

- Malayalam: Vilavu, Vilarmatam

- English: Elephant Apple, Wood apple, Curd Fruit, Monkey Fruit. (8)

Synonym: Feronia limonia. (8) 


\section{Plant description and distribution}

It is moderate size slow growing tree, with strait sharp strong spines. The tree grows up to the height of $450 \mathrm{~m}$. The fruits are sour and sweet. It is traditionally consumed as fruit and vegetable in Sri Lanka. It is indigenous in South India, Java, Myanmar, Malaysia and Ceylon and cultivated in many parts of India. (3)

\section{Chemical constituents}

The different parts of plant Feronia elephantum Correa consists different chemical constituents. The chemical composition of different part is given in the Table 1.

\begin{tabular}{|c|c|c|}
\hline $\begin{array}{l}\text { Plant } \\
\text { Part }\end{array}$ & Chemical Constituents & $\begin{array}{l}\text { Refer } \\
\text { ences }\end{array}$ \\
\hline Fruit & $\begin{array}{l}\text { Stigmasterol (Unripe fruit), Coumarins, } \\
\text { tyramine derivatives, beta carotene, } \\
\text { Vitamins (riboflavin and thyamine) }\end{array}$ & 3,10 \\
\hline Leaf & $\begin{array}{l}\text { Methyl chavicol, essential oil (terpinolen, } \\
\text { pinocarone, myrtenal, } \beta \text {-pinene, } Z \text { - } \\
\text { anethole etc.) }\end{array}$ & $\begin{array}{l}4, \\
11,12\end{array}$ \\
\hline Bark & $\begin{array}{l}\text { 2-Propenenitrile, 3-(3.4- } \\
\text { dimethoxyphenyl) }\end{array}$ & 6 \\
\hline Roo & $\begin{array}{l}\text { Monoterpenoid furano coumarin lactone } \\
\text { (fernoline), coumarins }\end{array}$ & 13 \\
\hline
\end{tabular}

\section{Pharmacological activites}

Anti-ulcer activity

- Mishra A et al., 2009 Studied Feronia elephantum Correa fruit pulp ethanolic extract against the gastric ulceration in rats induced by indomethacin. Standard drug was taken ranitidine for the comparison. The results suggested that the extract decreases the acid concentration of gastric fluid but were not potent as ranitidine and acute toxicity studies didn't show any mortality between the ranges of $250-5000 \mathrm{mg} / \mathrm{kg}$. (9)

- Muthulakshmi A et al., 2013 Studied Feronia elephantum Correa bark and leaf ethanol extract against the gastric ulceration in rats induced by indomethacin. Pretreatment with the extract showed decrease in the ulcerated area as well as volume \& acidity of the gastric juice. Results suggested that the plant consist the antiulcerogenic activity. (1)

\section{Antidiabetic activity}

- Gupta $R$ et al., 2009 Studied the anti-diabetic activity of ethanolic extract of unripe fruit of plant Feronia elephantum Correa in the streptozotocin induced diabetic male albino rats. The extract significantly reduced the blood glucose level of fasted, fed and streptozotocin induced diabetic rats. Histology of pancreatic $\beta$-cells showed degranulation of cells associated with blood glucose lowering was observed. (3)

- Mishra A et al., 2011 Studied the hypoglycemic as well as antidiabetic potential of methanolic extract of fruit pulp of plant Feronia elephantum Correa in glucose loaded animal and alloxan induced diabetic animals.
Results showed the extract decrease the blood glucose level and reduced rate of body loss as compare to the standard metformin. Results showed the methanolic extract of plant have significant antidiabetic activity. (2)

- Reddy et al., 2019 Studied in vitro $\alpha$-amylase and $\alpha$ glucosidase inhibition activity of methanolic and aqueous extract of fruit of plant Feronia elephantum Correa. All extracts showed inhibitory activity against the $\alpha$-amylase and $\alpha$-glucosidase enzymes. The results suggested that the aqueous and methanolic extract of plant fruit can be potential use in diabetic patients. (10)

\section{Antimicrobial and Antibacterial activity}

- Garg S et al, 2001 Studied antibacterial and antimicrobial activity of essential oil obtained from Feronia elephantum Correa against ten bacteria and ten fungi using filter paper disc agar diffusion technique. The oil exhibited strong activity against them. The results showed that leaves essential oil have antibacterial and antimicrobial activity. (4)

\section{Antioxidant and cytotoxic activity}

- Nithya $N$ et al., 2010 Evaluated in-vitro antibacterial and antioxidant activities of ethanolic extract of fruit of plant Feronia elephantum Correa. Antioxidant activity was assessed by estimating total flavonoids, phenols, tannins, total antioxidant activity and iron chelating activity. They also estimated the antioxidant activity against isolated bacteria. Results suggested that the extract have dose dependent and broad spectrum antibacterial activity. (5)

- Thirugnanasampandan $R$ et al., 2014 Studied essential oil obtained from of leaves of Feronia elephantum for antioxidant activity by DPPH free radical, hydroxyl radical scavenging, metal chelating and prevention of deoxyribose degradation, Results suggested that oil can be useful for food preservation and preparation. (11)

\section{Antitumor activity}

- Saima Y et al., 2000 Isolated acidic heteropolysaccharide from the plant chloroform-ethanol extract of Feronia elephantum Correa. The preliminary study in the murine model showed significant in vivo Ehrlich ascites carcinoma cell growth inhibition. (14)

\section{Antihistaminic activity}

- Chavan S et al., 2014 Studied various extracts of Feronia elephantum Correa bark using clonidine induced catalepsy and haloperidol-induced catalepsy in Swiss albino mice. Ethanol extract (50 mg/kg, ip) of the plant significantly inhibited clonidine-induced catalepsy. Thus the antihistaminic activity of Feronia elephantum may be due to polar constituents. (15)

\section{Hepatoprotective Activity}

- Mishra M et al., 2017 Evaluated hepatoprotective activity of ethanolic as well as aqueous extract of stem bark and Root of Feronia elephantum Correa against CCL4 induced Hepatic Damage in rat. On treatment with extracts at a dose of $50 \& 100 \mathrm{mg} / \mathrm{kg}$, the altered levels of Biochemical markers of Hepatic Damage were found to 
be at normal levels, from which it was concluded that Feronia elephantum Correa possess a strong hepatoprotective action against CCL4- Induced Hepatic damage in rats.(16)

\section{Antifungal Activity}

- Balamurugan $S$ et al., 2014 Evaluated anti-fungal activity of Feronia elephantum Correa extracts against Aspergillus niger, Penicillium, Candida albicans etc. using Agar well Diffusion assay taking Glucanazole as reference and Found that Methanolic fruit extracts possess strong anti-fungal activity against most of the strains. (17)

\section{Antifertility Activity}

- Muthulakshmi A et al., 2013 Studied the effect of ethanolic extract of Feronia elephantum Correa leaf and bark on male reproductive system of albino rats and found that there was a significant decrease in weight of testis, epididymis, and seminal vesicle. Increased FSH and estrogen serum levels as well as decreased LH and testosterone were also observed in hormonal assays. (18)

\section{Anti-Inflammatory Activity}

- Muthulakshmi Aet al., 2012 Investigated antiinflammatory activity of Feronia elephantum Correa leaf and bark extracts in animal models by orally administering dose of $200 \& 400 \mathrm{mg} / \mathrm{kg}$ body weight in test group and control group with $0.5 \% \mathrm{NaCl}$ (Saline) solution. Results showed that, ethanolic leaf extract possess potent anti-inflammatory activity. (19)

\section{Discussion}

Feronia elephantum Correa. Possess Anti-ulcer, Anti-diabetic, Antimicrobial, Antibacterial, Antioxidant, cytotoxic, Antitumor, Antihistaminic, Hepatoprotective, Antifungal, Anti-fertility and Anti-inflammatory. But still there may be number of active constituents, which will be present in various parts of this plant having important unexplored or hidden activities/potential.

\section{Conclusion}

This Review provides valuable details of the Plant Feronia elephantum Correa, which would be helpful for other researchers and scientists for further investigations and exploring properties present in this plant.

\section{References}

1. Muthulakshmi A, Margret RJ, Mohan V. Antiulcer effect of Feronia elephantum Correa leaf and bark extract in indomethacin induced albino rats. J of App Pharm Sci. 2013 3(4); S71-S74.

2. Mishra A, Garg G. Antidiabetic activity of fruit pulp of Feronia elephantum Corr. P'cog J. 2011; 3(20); 27-32.

3. Gupta R, Johri S, Saxena AM. Effect of ethanolic extract of Feronia elephantum Correa fruits on blood glucose levels in normal and streptozotocin-induced diabetic rats. Natur Prod rad. 2009; 8(1); 32-36.
4. Garg SC. Antimicrobial activity of the essential oil of Feronia elephantum Correa. Indian J of Pharm Sci. 2001; March-April; 155-157.

5. Nithya N, Saraswathi U. In vitro antioxidant and antibacterial efficacy of Feronia elephantum Correa fruit. Indian J of Nat Prod and Res. 2010; 1(3); 301-305.

6. Muthulakshmi A, Jothibai M, Mohan V. GC-MS Analysis of Bioactive Components of Feronia elephantum Correa (Rutaceae). J of App Pharm Sci. 2012; 2(2); 69-74.

7. https://indiabiodiversity.org/biodiv/species/show/ 261620 dated 28-05-2021 time 14.00 IST

8. http://iu.ff.cuni.cz/pandanus/database/details.php? id=714 dated 28-05-2021 time 15.00 IST

9. Mishra A, Arora S, Gupta R, Manvi, Punia R, Sharma A. Effect of Feronia elephantum (Corr) Fruit Pulp Extract on Indomethacin-induced Gastric Ulcer in Albino Rats. Tropical J of Pharm Res. 2009; 8(6); 509-514.

10. Reddy G, Reddy K, Reddy G. In vitro $\alpha$-Amylase and $\alpha$-Glucosidase inhibitory activity of Feronia elephantum fruit and Paspalum scrobiculatum grains. Asian $\mathrm{J}$ of Pharm and P'col. 5(S1); 42-47: 2019.

11. Thirugnanasampandan R, David D. In vitro antioxidant and cytotoxic activities of essential oil of Feronia elephantum Correa. Asian Pac J Trop Biomed. 2014; 4(4); 290-293.

12. Johsi R, Badakar V, Kholkute S, Khatib N. Chemical Composition and Antimicrobial Activity of the Essential Oil of the Leaves of Feronia elephantum (Rutaceae) from North West Karnataka. Nat Prod Com. 2011; 6(1); 141-143.

13. Pande C, Tewari G, Singh C, Singh S, Padalia RC. Chemical composition of the essential oil of Feronia elephantum Correa. Nat Prod Res. 2010; 24(19); 1807-1810.

14. Saima Y, Das A, Sarkar K, Sen A, Sr, Sur P. An antitumor pectic polysaccharide from Feronia limonia. Int J of Biol Macromol. 2000; 27; 333-335.

15. Chavan S, Jadhav R, Damale M, Pattan S. Antihistaminic effect of Feronia elephantum bark. World J of Pharm and Pharm Sci. 2014; 3; 1011-1016.

16. Mishra M, Mishra R, Balakrishnan N, Verma S. Hepatoprotective activity of aqueous and ethanol extracts of Feronia elephantum Correa. Stem bark and Root. Asian Pac. J. Health Sci. 2017; 4(4); 119-122.

17. Balamurugan S. Evaluation of the antifungal activity of various solvent extracts of Feronia elephantum correa (Rutaceae). Intl Lett of Natl Sci; 2014; 7; 29-34.

18. Muthulakshmi A, Jothibai Margret R, V. R. Mohan. Antifertility Effect of Ethanol Extracts of Feronia elephantum Correa Leaf and Bark on Male Albino Rat. Int J of Pharm Sci and Drug Res 2013; 5(1); 23-27

19. Muthulakshmi A, Jothibai M , Mohan V. AntiInflammatory Activity Of Ethanol Extract Of Leaf And Bark Of Feronia Elephantum Correa. J. Curr. Chem. Pharm. Sc. 2012; 2(4); 266-270. 